УДК 346.52

DOI https://doi.org/10.32849/2663-5313/2020.12.14

\title{
Тетяна Швидка,
}

докт. юрид. наук, дочент, адвокат,

асистент кафедри господарського права

Начіонального юридичного університету імені Ярослава Мудрого

\section{Катерина Халецька,}

студентка I курсу магістратури

господарсько-правового факультету

Начіонального юридичого університету імені Ярослава Мудрого

\section{КОМПЛАЄНС-КОНТРОЛЬ У СИСТЕМІ КОРПОРАТИВНОГО УПРАВЛІННЯ ГОСПОДАРСЬКИМИ ТОВАРИСТВАМИ}

\begin{abstract}
Стаття присвячена проблемним питанням у сфері корпоративного управління та внутрішнього контролю господарських товариств. Для повного розуміння иих понять розглянуто різні наукові підходи до тлумачення корпоративного управління, його систему й кониепиї впровадження ефективного корпоративного управління на підприємствах. У статті пропонується визначення нового підходу до визначення корпоративного управління з урахуванням суб'єктивної сторони здійснення корпоративного управління. Установлено, що для забезпечення ефективного корпоративного управління на підприємстві існує необхідність запровадження комплаєнс-контролю. Також зазначається, що в українській науковій літературі досліджується переважно питання антимонопольного та податкового контролю. З'ясовано, що комплаєнс-контроль в Україні законодавчо передбачений лише для банківських установ і професійних учасників фондового ринку. Тому постає питання про розширення сфери внутрішнього контролю на підприємстві й запровадження такого контролю в інших господарських товариствах. Стаття має на меті проведення аналізу чинного законодавства Украйни, що регулює питання внутрішнього контролю в системі корпоративного управління за різними сферами діяльності підприємства, а також вивчення необхідності закріплення на законодавчому рівні положень про механізм упровадження та функиіонування комплаєнс-контролю в усіх господарських товариствах.

Під час розкриття проблеми досліджено наукові підходи до визначення корпоративного управління та його ефективності, визначено місие контролю за дотриманням вимог законодавства в системі корпоративного управління, зроблено аналіз видів комплаєнс-контролю, які виділяють украйнські вчені, а також установлено, у яких сферах господарської діяльності законодавчо передбачено впровадження системи комплаєнсу. Сучасний стан украйнського контролю за дотриманням законодавства в системі корпоративного управління вимагає досліджень $і$ критичного аналізу його нормативної бази в Украйні для визначення ефективних напрямів розвитку законодавства в иій галузі. Зрештою, визначено необхідність контролю за дотриманням вимог у системі корпоративного управління господарських товариств у розрізі дослідження напрямів підвищення ефективності такого управління.
\end{abstract}

Ключові слова: корпоративне управління, ефективність корпоративного управління, комплаєнс-контроль, внутрішній контроль, контроль за дотриманням вимог, підприємство, господарське товариство, законодавство.

Постановка проблеми. Сьогодні Україна перебуває в умовах активної політичної перебудови, яка складається з дій щодо створення та вдосконалення національної законодавчої бази з орієнтацією на міжнародну практику. Важливою сферою реформування українського законодавства є встановлення системи внутрішніх контрольних заходів корпоративного управління для всіх господарських товариств з метою забезпечення їх прозорості й надійності. Одним зі складни- ків корпоративного управління є комплаєнсконтроль, за допомогою якого забезпечується ефективна діяльність компанії у правовому полі. Сьогоднішній стан комплаєнс-контролю в корпоративному управлінні в нашій країні потребує дослідження та критичного аналізу з погляду вітчизняної нормативноправової бази задля визначення ефективних напрямів розвитку законодавства в цій сфері. Також необхідно звернути увагу, що в українській науковій літературі досліджуються 
питання здебільшого антимонопольного та податкового комплаєнс-контролів, однак установлення внутрішнього контролю щодо діяльності господарського товариства потребує подальших наукових досліджень.

Дослідженнями комплаєнс-контролю в системі корпоративного управління займалися О.В. Морозов, Н.П. Карачина, Т.П. Халімон [1], М.В. Кочеров [6], Л.Л. Калініченко [5], П.В. Коломієць [7], О.В. Михайленко [4] та інші. Однак питання вдосконалення законодавства щодо корпоративного управління господарських товариств і закріплення на законодавчому рівні комплаєнс-контролю як елементу системи корпоративного управління залишається відкритим.

Мета статті полягає в аналізі нормативноправової бази, що регулює питання внутрішнього контролю за різними сферами діяльності товариства, а також у доведенні необхідності закріплення на законодавчому рівні положень про механізм здійснення в усіх господарських товариствах комплаєнс-контролю.

Відповідно до поставленої мети, у статті мають бути вирішені такі завдання:

- дослідити деякі підходи до визначення поняття корпоративного управління;

- охарактеризувати місце комплаєнсконтролю в системі корпоративного управління та його види;

- установити, у яких сферах господарської діяльності законодавчо передбачено впровадження системи комплаєнсу;

- розглянути напрями підвищення ефективності корпоративного управління господарськими організаціями.

Виклад основного матеріалу. Дієвість функціонування будь-якого господарського товариства залежить від ефективності корпоративного управління цього суб'єкта господарювання. Важливим у діяльності господарського товариства $є$ забезпечення довіри з боку контрагентів, інвесторів і клієнтів, що надає останнім упевненості в тому, що товариство провадить свою діяльність із дотриманням законодавства, стандартів, екологічної безпеки, безпечності та якості виготовленої продукції тощо. Надійність товариства надає контрагентам, інвесторам і клієнтам упевненості в добросовісній діяльності цього господарюючого суб'єкта й гарантії для підписання з ним договорів, здійснення фінансування з боку інвесторів тощо. Усе це залежить від вдалої роботи 3 корпоративного управління, що передбачає застосування надійних механізмів управління та контролю, відкритість і прозорість у діяльності, захист прав інвесторів тощо.
У науковій літературі існують різні підходи до визначення сутності корпоративного управління, узагальнення та систематизації, зокрема їх розглянули в наукових працях О.В. Морозов, Н.П. Карачина та Т.П. Халімон. Отже, до основних підходів до визначення поняття корпоративного управління можна зарахувати частковий (внутрішня архітектура), суспільний (зовнішні відносини), нормативний, економічний, управлінський, організаційний, юридичний, фінансовий, соціально-економічний [1, с. 12-15] Така велика кількість підходів дає підстави вважати, що корпоративне управління - це багатоаспектне явище, яке стосується всіх сфер діяльності суб'єкта господарювання. Згадані вище науковці в монографії під корпоративним управлінням розуміють регламентований механізм забезпечення захисту й урахування інтересів основних груп соціальних агентів-учасників корпоративних відносин з метою забезпечення максимально можливої соціально-економічної результативності підприємства [1, с. 17].

Однак, беручи до уваги те що корпоративне управління здійснюють певні суб'єкти на підприємстві, доречно буде визначити, що корпоративне управління - це керівництво діяльністю господарського товариства через його органи управління 3 використанням розроблених методів і напрямів, за допомогою яких здійснюється контроль за діяльністю й досягненням мети товариства, виконанням поставлених завдань, здійсненням фінансових операцій, а також керівництво у сфері забезпечення відповідності діяльності товариства вимогам законодавства України. Якщо звернутися до Принципів корпоративного управління Організації економічного співробітництва та розвитку, прийнятих у 1999 році Радою ОЕСР, то в них зазначається, що ефективне корпоративне управління допомагає в забезпеченні ефективного використання капіталу товариствами. Крім того, за його допомогою зберігається довіра з боку національних та іноземних інвесторів, а також сприяння залученню довгострокового капіталу [2]. Цей документ також установлює рекомендації щодо закріплення в національних стандартах корпоративного управління конкретних проблем і шляхів їх подолання.

Ефективність управління є абстрактним поняттям, тому в науковій практиці сформувалися певна кількість підходів до його тлумачення, основними з яких можна виділити цільовий, системний, внутрішньо-організаційний і конкурентний підходи. У контексті теми статті доречним буде розглянути системний підхід до визначення ефективності 
корпоративного управління. Системний підхід підкреслює критерії, якими забезпечується виживання організації в довгостроковому періоді, зберігаючи стабільність внутрішнього соціального організму й успішно взаємодіючи 3 навколишнім середовищем. Такий підхід більше зосереджується не на визначених цілях, а на засобах, необхідних для їх досягнення [3, с. 466-470]. 3 аналізу системного підходу можна констатувати, що ефективність управління досягається за умови якісної роботи кожного елементу системи корпоративного управління та підприємства загалом.

Для побудови та підтримки корпоративного управління світова практика пропонує використання концепції «трьох ліній захисту» підприємства, яка координує процеси керування ризиками та внутрішнього контролю за рахунок чіткого визначення й розмежування відповідних функцій та обов'язків. Відповідно до цієї концепції, основними функціями другої лінії захисту господарського товариства є встановлення певних підрозділів, які здійснюють контроль за діяльністю товариства, таких як ризик менеджмент, управління бізнес-процесами, служба безпеки та комплаєнс. У розрізі теми статті варто звернути увагу на поняття комплаєнсу та його роль у системі корпоративного управління господарськими товариствами.

Комплаєнс означає законність дій компанії загалом і кожного іï співробітника. В очах контрагентів комплаєнс-перевірка підтверджує, що компанія відповідає вимогам стандартів і правилам, що встановлюються законодавством, умовам договору [4, с. 121]. Отже, система управління комплаєнс-контролю - це заходи, які мають на меті проведення аналізу та дослідження діяльності господарського товариства в розрізі дотримання всіма співробітниками встановлених правил і забезпечує знаходження діяльності такого товариства в правовому полі. Іншими словами, завданням комплаєнс-контролю є створення системи внутрішнього контролю, на меті якого є запобігання виникненню ризиків і/або їх ліквідація на підприємстві.

До функцій комплаєнс-контролю можна зарахувати розробку та закріплення на локальному рівні підприємства корпоративної політики, стандартів у сфері діяльності підприємства, серед яких - комплаєнс-програми, проведення аналізу відповідності корпоративної політики чинному законодавству України, перевірки на дотримання всіх чинних норм і правил регулювання діяльності підприємства та відповідність усіх нормативно-методичних і стратегічних докумен- тів, а також звітування про висновки такої перевірки й у разі необхідності здійснення коригувальних заходів [4, с. 121].

Комплаєнс-програма розуміється як локальний акт господарського товариства, що включає сукупність внутрішніх правил і процедур, реалізація яких у кінцевому підсумку приводить до досягнення цілей товариства та прозорості його діяльності. Така програма може включати розроблення й затвердження кодексу корпоративної поведінки та етики, політики про запобігання шахрайству, політики про вирішення конфліктів на самому підприємстві та з контрагентами, політики про конфіденційність даних тощо. Задля належної реалізації комплаєнс-програми необхідно створити постійно діючі підрозділи контролю (комплаєнс-підрозділ) або визначити окрему посадову особу (комплаєнс-офіцера) [5, с. 244-245].

У науковій літературі комплаєнс поділяють на певні види, основними 3 яких $\epsilon$ антимонопольний комплаєнс і податковий комплаєнс. М.В. Кочеров у роботі визначає антимонопольний комплаєнс як систему внутрішнього забезпечення відповідності діяльності суб'єкта господарювання вимогам антимонопольного законодавства. Виходячи із цього визначення, можна виокремити завдання такого комплаєнсу, що полягає у виявленні ризиків порушення антимонопольного законодавства, управлінні цими ризиками, контролі за виконанням заходів, спрямованих на їх усунення, та оцінюванні ефективності функціонування підприємства 3 дотриманням норм антимонопольного законодавства. Однак автор зазначає, що, як і в будь-якій іншій внутрішній системі контролю, важливою передумовою запровадження комплаєнсу $є$ зацікавленість керівництва підприємства в його ефективній роботі й у функціонуванні такої системи на основі принципів інформаційної відкритості, послідовності та безперервності [6].

Податковий комплаєнс - система заходів, метою яких є дотримання господарським товариством як платником податків вимог законодавства зі сплати єдиного внеску на загальнообов'язкове державне соціальне страхування, податкового законодавства, а також належна та своєчасна сплата податків, зборів та інші платежів. П.В. Коломієць, яка в наукових роботах досліджувала сферу податкового комплаєнсу, зазначає, що його система дасть змогу мінімізувати ризики недотримання платниками вимог податкового законодавства, максимально спростити подання звітності та сплату податків, що буде діяти на принципи прозорості, спільно вирішувати про- 
блеми й усувати перешкоди в забезпеченні податкової безпеки, а також установити між суб'єктами господарювання та державою відносини, які грунтуються на довірі й партнерстві [7, с. 260-261].

На нашу думку, для провадження ефективного корпоративного управління необхідно не лише запровадження антимонопольного та податкового комплаєнс-контролю. Наприклад, доречним буде розробити на підприємстві комплаєнс-контроль у сфері регулювання та перевірки добору кадрів, або, іншими словами, організаційно-кадровий комплаєнс. Метою такого комплаєнсу є здійснення перевірок відповідності кадрового потенціалу підприємства його цілям і завданням, а також проведення аналізу якісних і кількісних характеристик персоналу, запровадження принципів відбору кадрів, установлення певних правил поведінки та етики для працівників підприємства.

Також однією зі сфер господарської діяльності, що потребує встановлення комплаєнс-контролю в господарському товаристві, $€$ діяльність такого товариства 3 додержанням норм природоохоронного законодавства. Законодавчо встановлено принцип екологічного підприємства, яким нехтують багато підприємців, або не звертають увагу на таке порушення через необачність. Комплаєнсконтроль дасть змогу уникнути можливості порушення норм екологічного законодавства та забезпечить діяльність підприємства в рамках закону.

Система комплаєнс-контролю в Україні $€$ новим явищем, яке запроваджено лише в деяких сферах господарської діяльності. Отже, уперше в Україні комплаєнс-контроль передбачений у сфері банківської діяльності рішенням Правління Національного банку України «Про схвалення Методичних рекомендацій щодо організації корпоративного управління в банках України» від 3 грудня 2018 року № 814-рш (далі - Рішення № 814рш) [8], а також Постановою Правління Національного банку України «Про затвердження Положення про організацію системи управління ризиками в банках України та банківських групах» від 11 червня 2018 року № 64 [9]. Банківські установи в діяльності у сфері корпоративного управління користуються концепцією трьох ліній захисту підприємства. Пунктом 120 Рішення № 814-рш запроваджено діяльність комплаєнс-підрозділу як другу лінію захисту підприємства, що має на меті проведення перевірки за дотриманням усіх чинних норм і правил, регулювання діяльності підприємства, звітування про висновки такої перевірки, а також розробку та закріплення на локальному рівні підприємства корпоративних політик і стандартів [8].

Відповідно до пункту 121 Рішення № 814-рш, підтвердженням належного функціонування моделі трьох ліній захисту в банківській діяльності $є$ ефективність та економічна доцільність здійснюваних банком операцій; обачливе (обережне) ведення банківської та іншої діяльності банку, уключаючи збереження його активів та інвестицій; своєчасне й належне виявлення, вимірювання, моніторинг, контроль, звітування та пом'якшення за всіма видами ризиків; достовірність фінансової та статистичної звітності (уключаючи звітність, що подається до Національного банку, й управлінську звітність, що подається до органів управління банку), інформації щодо фінансово-господарської діяльності банку, що надається як внутрішнім, так зовнішнім користувачам; надійність інформаційних технологій, управлінських та облікових процесів, що базуються на чіткому визначенні обов'язків, розподілі повноважень і підзвітності; відповідність діяльності банку законодавству України, нормативно-правовим актам Національного банку, а також внутрішнім документам банку (політиці, процедурам, рішенням органів управління банку) [8].

По шляху запровадження комплаєнсконтролю також пішла й Національна комісія цінних паперів та фондового ринку, яка прийняла Рішення «Про затвердження Стандартів корпоративного управління в професійних учасниках фондового ринку» від 30 липня 2019 року № 420. Метою запровадження інституту комплаєнс для професійних учасників фондового ринку є забезпечення надійної діяльності таких учасників, гарантування захисту прав інвесторів і споживачів фінансових послуг, а також створення середовища на фінансових ринках України на засадах конкурентності. Система корпоративного управління професійними учасниками фондового ринку має стати невід'ємною частиною системи управління ризиками, що матиме на меті розроблення та підтримку внутрішніх правил і процедур, спрямованих на запобігання виникненню ризиків та управління ризиками, а також уживання заходів, спрямованих на мінімізацію зазначених ризиків [10].

\section{Висновки}

Отже, узагальнюючи вищевикладене, можна резюмувати таке:

1. У науковій літературі виділяють різні підходи до визначення корпоративного управління. Беручи до уваги суб'єктивну сторону здійснення корпоративного управ- 
ління на підприємстві, можна дати таке визначення: корпоративне управління - це керівництво діяльністю господарського товариства через його органи управління з використанням розроблених методів і напрямів, за допомогою яких здійснюється контроль за діяльністю й досягненням мети товариства, виконанням поставлених завдань, здійсненням фінансових операцій, а також керівництво у сфері забезпечення відповідності діяльності товариства вимогам законодавства України.

2. 3 метою забезпечення ефективності корпоративного управління господарськими товариствами існує необхідність запровадження комплаєнс-контролю. Створення такого інституту можливе лише в разі наявності зацікавленості керівництва в ефективній роботі підприємства й у функціонуванні такої системи на основі принципів інформаційної відкритості, прозорості, послідовності й безперервності. Функціонування комплаєнс-контролю слугуватиме підтвердженням того, що компанія відповідає вимогам стандартів і правилам, що встановлюються законодавством.

3. Станом на сьогодні законодавчо врегульовано питання запровадження системи комплаєнс-контролю в банківській сфері. Постановами та рішення Правління Національного банку України визначено структуру функціонування комплаєнс-контролю в системі корпоративного управління Також потрібно зазначити, що, відповідно до Рішення Національної комісії цінних паперів та фондового ринку № 420, із 2019 року внутрішній контроль за дотриманням норм законодавства запроваджується й для професійних учасників фондового ринку.

4. Сьогодні українським законодавством не регламентовано порядок створення та функціонування комплаєнс-контролю в системі корпоративного управління, не визначено місце його підрозділів у системі господарських товариств, вимоги до осіб, які відповідальні за здійснення комплаєнсконтролю, тощо. Тому основними напрямами підвищення ефективності комплаєнсконтролю можна визначити законодавче закріплення порядку його впровадження в господарських товариствах; визначення системи здійснення внутрішнього контролю на підприємстві; упровадження системи комплаєнсу не лише в банках і професійних учасників фондового ринку, а й в інших підприємствах з метою дотримання принципу прозорості ведення господарської діяльності.

\section{Список використаних джерел:}

1. Морозов О.В., Карачина Н.П., Халімон Т.П. Корпоративне управління на підприємствах України: постприватизаційний етап еволюції : монографія. Вінниця : УНІВЕРСУМ, 2007. $180 \mathrm{c}$.

2. Принципи корпоративного управління OECP : Звід принципів Організації економічного співробітництва та розвитку від травня 1999 / Організації економічного співробітництва та розвитку. URL: https://old.bank.gov.ua/doccatalog/ document?id=36989 (дата звернення: 23.10.2020).

3. Задихайло Д.В., Кібенко О.Р., Назарова Г.В. Корпоративне управління : навчальний посібник. Харків : Еспада, 2003. 688 с.

4. Михайленко О.В., Риштун Х.Ю. Ефективна система побудови комплаєнс-контролю в банківських установах. Проблеми системного підходу в економіці. 2018. № 3 (65). С. 120-126.

5. Калініченко Л.Л. Теоретичні аспекти функціонування комплаєнсу у вітчизняних банках. Науковий вісник Херсонського Державного університету. Серія «Економічні науки». 2014. № 6. Ч. 4. С. $242-245$.

6. Кочеров М.В. Антимонопольний комплаєнс в Україні: коли варто починати? Юридична газета online. 2019. № 15 (669). URL: https:// yur-gazeta.com/dumka-eksperta/antimonopolniykomplaens-v-ukrayini-koli-varto-pochinati.html (дата звернення: 23.10.2020).

7. Коломієць П.В. Погляди науковців стосовно комплаєнсу як елементу податкової безпеки України. Право та суспільство. 2020. № 2. Ч. 2. С. 258-263.

8. Про схвалення Методичних рекомендацій щодо організації корпоративного управління в банках України : Рішення Правління Національного банку України від 3 грудня 2018 року № 814-рш / Правління Національного банку України. URL: https://zakon.rada.gov.ua/laws/show/ vr814500-18\#Tехt (дата звернення: 22.10.2020).

9. Про затвердження Положення про організацію системи управління ризиками в банках України та банківських групах : Постанова Правління Національного банку України від 11 червня 2018 року № 64 / Правління Національного банку України. URL: https://zakon.rada.gov.ua/ laws/show/v0064500-18\#Text (дата звернення: 22.10.2020).

10. Про затвердження Стандартів корпоративного управління в професійних учасниках фондового ринку : Рішення Національної комісії 3 цінних паперів та фондового ринку України від 30 липня 2019 року № 420 / Національна комісія 3 цінних паперів та фондового ринку України. URL: https://www.nssmc.gov.ua/proects_of_regular/ pro-zatverdzhennya-standartv-korporativnogoupravlnnya-v-profesynih-utchasnikah-fondovogorinku/ (дата звернення: 24.10.2020). 
Tetiana Shvydka, Kateryna Khaletska. Compliance control in the system of corporate governance of business associations

This article is devoted to problematic issues in the field of corporate governance and internal control in enterprises. The article is proposed to define a new approach to the definition of corporate governance, taking into account the subjective side of corporate governance. It is established that in order to ensure effective corporate governance at the enterprise there is a need to introduce compliance control. It is also noted that the Ukrainian scientific literature examines the issues of mainly antitrust and tax control. The article is established that compliance control in Ukraine is provided by law only for banking institutions and professional participant of the securities market. Therefore, the question arises about expanding the scope of internal control in the enterprise and the introduction of such control in other business associations. The article aims are to analyze the current legislation of Ukraine, which regulates internal control in the corporate governance system in various areas of the enterprise, as well as to study the need to enshrine at the legislative level provisions on the mechanism of implementation and operation of compliance control in all business associations.

During the disclosure of the problem, scientific approaches to the definition of corporate governance and its effectiveness are studied, the place of control over compliance with the law in the corporate governance system is characterized, the types of compliance control identified by Ukrainian scientists are analyzed, and also establishes in which spheres of economic activity the introduction of the compliance system is legally provided. The current state of Ukrainian control over compliance with the law in the corporate governance system requires research and critical analysis of its regulatory framework in Ukraine to determine effective directions for the development of legislation in this area. Finally, the article identifies the need to monitor compliance with the requirements in the system of corporate governance of business associations in terms of research to improve the efficiency of such management.

Key words: corporate governance, effective corporate governance, compliance control, internal control, control over compliance with requirements, enterprise, business associations, legislation. 